\title{
PERSEPSI KONSUMEN TERHADAP PRODUK PRIVATE LABEL INDOMARET ( STUDI PADA INDOMARET BANJARMASIN KELURAHAN BENUA ANYAR)
}

\author{
Nurul Hasanah \\ Email: nurulhasanaharif@gmail.com
}

Sekolah Tinggi Ilmu Administrasi Amuntai

\begin{abstract}
The results of this study Consumers prefer private label products because consumers believe that prices are relatively cheap and have good quality. seen from the interview table that the price of private label products is cheaper. Apart from the price, the quality of private label products in Indomaret Banjarmasin is the same quality as the national brand product. In the packaging of private label products slightly less attractive than the national brand products, while for the value of the function for private label products can be an alternative choice to substitute the national brand products. From the Rating Scale rating Private label products are located at "good enough" intervals with a value of 900 .
\end{abstract}

Keywords: Perception, Private Label and National Brand

\section{PENDAHULUAN}

Bisnis ritel atau eceran mengalami perkembangan cukup pesat, ditandai dengan semakin banyaknya bisnis ritel tradisional yang mulai membenah diri menjadi bisnis ritel modern maupun munculnya bisnis ritel modern yang baru. Dengan perkembangannya, pengelolaan ritel modern membutuhkan dukungan teknologi khusunya bidang informasi yang memungkinkan bisnis ritel mampu menyediakan produk, pekayaan dan pemrosesan yang cepat dan memuaskan pelanggan ( Utami,2010:4)

Menurut Apindo, bisnis ritel di Indonesia dapat dibedakan menjadi 2 kelompok besar, yakni ritel tradisional dan ritel modern. Namun dalam perkembangannya, retail modern memiliki pertumbuhan lebih cepat dibandingkan dengan retail tradisional. Banya sekali jenis retail modern di Indonesia salah satunya adalah pasar modern. Saat ini di Indonesia terdapat tiga jenis pasar modern yaitu 
Minimarket, Supermarket dan Hypermarket.

Pertumbuhan jumlah ritel di Indonesia juga diikuti dengan semakin banyaknya produk private label di pasaran. Produk private label adalah salah satu cara peritel untuk memenangkan persaingan untuk merebut segmen konsumen. Private label adalah merek produk yang dibuat dan hanya tersedia untuk djual oleh ritel (Utami, 2014 : 223). Salah satu keuntungan merek privat adalah meningkatkan citra toko (Utami, 2008 : 213). Dursun et al (2011) private label dikenal sebagai merek toko, merek sendiri, merek pengecer, dan merek distributor grosir sendiri. Private label adalah nama yang dirancang oleh grosir atau pengecer dan diawasi lebih baik, tidak dijual oleh pengecer dan pelanggan pesaing langsung.

Menciptakan sebuah persepsi yang baik bagi konsumen adalah pekerjaan yang tidak mudah. Peritel harus menciptakan persepsi tentang image toko yang baik kepada konsumen, agar konsumen berminat untuk kembali ke toko kita. Image adalah suatu bayangan atau gambaran yang ada didalam benak seseorang yang timbul karena emosi atau reaksi terhadap lingkungan sekitarnya, (Sopian dan Syihabudhi, 2008: 138). Maka citra toko (store image) mempunyai peranan yang sangat penting dalam hal perkembangan dan kesuksesan private label sebuah perusahaan ritel.

Indomaret adalah salah satu bisnis ritel di Indonesia yang menyediakan produk private label. Indomaret juga merupakan ritel yang mendominasi pertumbuhan jumlah ritel di Indonesia. Selain itu, persebaran gerai indomaret di Indonesia sangatlah luas ( http://www.datacon.cp.id/Ritel-2011

profil industri.html). hal ini dapat dilihat dari tersebarnya Indomaret di Pulau Jawa, Sumatera , Kalimantan dan di pulau yang lainnya. Indomaret juga merupakan pelopor konsep waralaba dibidang minimarket Indonesia. Indomaret pertama kali didirikan pada tahun 1988 dan didirikan pertama kali untuk kebutuhan karyawan, keterampilan dalam pengoperasian toko dan pergeseran perilaku konsumen untuk memenuhi kebutuhannya.

Muller (2006) mengatakan bahwa konsumen memiliki persepsi mengenai kualitas produk private label sama dengan produk dari national brand. 
Sedangkan untuk persepsi harga, produk private label memiliki harga yang relative kaku dibandingkan dengan penetapan harga produk national brand .Hal ini disebabkan Karena perubahan jumlah konsumsi untuk produk national brand. Alasan utama konsumen membeli produk private label adalah alasan harga namun dengan meningkatkan kualitas dari produk private label, maka konsumen akan tetap memilih produk private label dibandingkan dengan national brand ( Krisna,2011).

Produk private label jarang dipromosikan dan produk private label diposisikan sebagai produk alternative yang lebih murah dibandingkan dengan produk national brand ( Nenycz,2011) . Konsumen di Indonesia sebagian besar mempunyai persepsi bahwa kualitas produk national brand dan private label sama baiknya. Konsumen menjatuhkan pemilihan terhadap produk national brand untuk mengantisipasi kepuasan yang diharapkan oleh konsumen tersebut ( Purba, 2012). Berdasarkan uraian di atas, maka masalah penelitian dalam penelitian ini tentang "persepsi konsumen terhadap produk private label Indomaret dibandingkan dengan national brand di Banjarmasin”.

\section{METODE PENELITIAN}

Pendekatan penelitian dalam penelitian ini adalah kualitatif. Kualitatif dinamakan sebagai metode baru, Karena popularitasnya belum lama, dinamakan metode postpositivistik Karena berlandaskan pada filsafat postpositivisme. Metode ini disebut juga sebagai metode artistik, Karena proses penelitian lebih bersifat seni.

Metode yang digunakan dalam penelitian ini adalah metode deskriptif, yaitu suatu metode dalam meneliti suatu sekelompok masyarakat, suatu objek, suatu set kondisi, suatu sistem pemikiran ataupun suatu kelas, peristiwa pada masa sekarang.

Penelitian ini mengambil objek pada Indomaret yang ada di Banjarmasin tepatnya di Kelurahan Banjarmasin Utara. Penulis memilih lokasi penelitian disini Karena di daerah Banjarmasin Utara banyak terdapat Indomaret. Instrumen yang digunakan dalam penelitian ini adalah berupa kuesioner dengan menggunakan Rating Scale. Penggunaan Rating Scale ini didasarkan pada kegunaan yang sesuai untuk mengukur pendapat, sikap dan persepsi seseorang atau sekelompok 
Volume 3 Nomor 2, Oktober 2017

orang tentang permasalahan sosial. (Sugiono, 2012 : 132).

\section{HASIL PENELITIAN DAN PEMBAHASAN}

Untuk mengetahui persepsi konsumen terhadap produk private label peneliti juga melakukan wawancara dengan lima orang responden. Dari hasil wawancara dapat disimpulkan bahwa :

Pilihan konsumen pada saat dihadapkan dengan produk private label dan produk national brand

Konsumen lebih memilih produk private label karena konsumen mempercayai bahwa harga yang relative murah mempunyai kualitas yang bagus. Berdasarkan hasil wawancara dengan beberapa responden, mereka hampir semuanya memilih produk private label. Berikut ini beberapa pernyataan yang dikemukakan oleh responden tentang produk private label dan produk national brand.

“ menurut saya... produk private label harganya lebih murah, meskipun harga lebih murah dibandingkan dengan produk national brand tetapi menurut saya kualitasnya tetap bagus. ( responden 2).
“ saya lebih percaya kepada produk national brand, Karena iklannya ada $d T V .($ responden 4$)$.

“ kalau saya apa iut produk national brand atau produk private label asal harga lebih murah, tentu saya memilih harga yang lebih murah. ( responden 5).

\section{Persepsi Konsumen Terhadap Produk} Private Label Indomaret Banjrmasin

\section{Persepsi Nilai}

Pada saat responden diberi pertanyaan mengenai nilai fungsional produk private label, semua responden memberikan pernyataan bahwa sebenarnya produk private label samasama memberikan fungsi dan maanfaat bagi konsumen. Responden no 1 memberikan pernyataan tentang nilai fungsional suatu barang .

Menurut saya dalam membeli produk yang saya lihat pertama kali adalah harga dan fungsinya.( responden 2)

Menurut saya produk yang dijual di Indomaret fungsinya sesuai dengan harga .( responden 4)

Berdasarkan pernyataan yang diungkapkan responden dapat ditarik sebuah kesimpulan bahwa nilai fungsional suatu produk yang didapat 
oleh konsumen menggunakan produk private label Indomaret sama seperti fungsional yang didapatkan konsumen saat membeli produk national brand.

\section{Persepsi Harga}

Berdasarkan pernyataan yang dikemukakan oleh semua responden, konsumen ,menjatuhkan pilihan untuk membeli produk private label Indomaret Karena harganya yang lebih murah dibandingkan dengan produk lainnya. Berikut ini adalah beberapa pernyataan responden tentang persepsi harga produk private label yang ada di Indomaret Banjarmasin.

"menurut saya produk private label yang dijual di Indomaret Banjarmasin harganya lebih murah dibandingkan dengan produk national brand. (responden 1).

" kalau saya sebagai konsumen lebih memilih harga yang lebih murah atau terjangkau.( responden 2)

Responden 2 yang merupakan ibu rumah tangga dengan pendapatan terbatas mengungkapkan bahwa dengan membeli produk private label Indomaret karena harganya yang lebih murah dibandingkan produk national brand. Responden 2 juga mengatakan bahwa produk private label memiliki harga yang terjangkau untuk konsumen yang memiliki pendapatan terbatas. Menurut Kotler (2009), konsumen memilih produk private label Karena dapat menghemat biaya sebesar $30 \%$. Jadi dapat diambil kesimpulan untuk persepsi mengenai harga bahwa konsumen lebih memilih produk private label dibandingkan dengan produk national brand.

\section{Persepsi Kemasan}

Persepsi kemasan mengenai kemasan produk private label sangantlah subjektif dan beraneka ragam. Banyak pernyataan yang dilontarkan responden dalam menanggapi pertanyaan kemasan produk private label Indomaret.

"kalau menurut saya kemasan produk private label yang dijual di Indomaret Banjarmasin kemasannya lebih menarik dibandingkan dengan poduk national brand.(responden 5).

Dari hasil wawancara dapat diambil kesimpulan bahwa setiap kali konsumen membeli barang yang dilihat terlebih dahulu adalah kemasan dari produk itu. Dari hasil wawancara ini sama dengan penelitian yang ditemukan oleh Bahaduri Witisono ( 2010 ) yang menyatakan bahwa kemasan merupakan faktor pertama untuk konsumen membeli suatu produk. 


\section{Persepsi Kualitas}

Produk private label dianggap sebagai produk yang memiliki kualitas rendah, harga murah, rasa tidak enak dan kemasan kurang menarik. Padahal tidak semua produk privat label yang dianggap seperti itu ( Monroe,1997). Konsumen berpersepsi bahwa kualitas produk private label dianggap kurang berkualitas, itu bias dilihat dari harganya yang lebih murah dari produk national brand. Hal ini seperti yang diungkapkan oleh beberapa responden.

"menurut saya kualitas produk private label kualitasnya kurang bagus dibandingkan kualitas produk national brand. Itu dilihat dari harga yang lebih murah.( responden 4)

Dari pernyataan diatas dapat diambil kesimpulan bahwa ada sebagian konsumen yang menyukai kualitas produk national brand dan ada juga konsumen yang menyukai kualitas produk private label. Itu semua terserah kepada konsumen untuk membeli produk yang mereka kehendaki sesuai dengan harga, kualitas, fungsi dan kemasan dari produk yang mereka pilih.

\section{Persepsi konsumen terhadap produk national brand}

Produk national brand dianggap sebagai produk yang menawarkan kualitas yang lebih tinggi dari produk private label ( Geyskens et al,20I0). Dari hasil wawancara yang dilakukan 2 dari 5 responden menyatakan lebih memilih produk national brand dibandingkan produk private label adalah kualitas produk dan kemasan.

"kualitas produk national brand lebih bagus disbanding produk private label yang dijual di Indomaret. ( responden 2).

" kemasan atau packaging dari produk national brand lebih menarik dari kemasan produk private label ( responden 4)

Dua responden menyatakan bahwa produk national brand sudah tidak asing lagi di dengar dan banyak iklan yang memuat produk national brand $\mathrm{di}$ beberapa media. Dan menurut pernyataan mereka juga bahwa kemasan produk national brand lebih menarik dibandingkan produk private label.

Dari hasil perhitungan melalui metode Rating Scala, maka diperoleh jumlah skor hasil pengumpulan data 900. Dengan demikian persepsi konsumen terhadap produk private label menurut 
30 responden itu $\mathbf{7 5 \%}$ dari kriteria yang

ditetapkan. Hal ini secara kontinum

300

Sangat tidak baik

600

$$
\text { kurang baik }
$$

dapat dibuat kategori sebagai berikut :

Nilai 900 termasuk dalam kategori interval " cukup baik ". Berarti produk private label pada Indomaret Banjarmasin cukup diminati oleh konsumen.

Dari hasil wawancara dengan 5 responden, maka perbandingan persepsi konsumen mengenai produk private label dan national brand dengan tabel sebagai berikut :

Tabel 4.1: Perbandingan persepsi konsumen mengenai produk private label dan produk national brand.

\begin{tabular}{|c|c|c|}
\hline $\begin{array}{l}\text { Persepsi } \\
\text { konsumen }\end{array}$ & Private Label & National Brand \\
\hline Harga & $\begin{array}{l}\text { Harga produk private label } \\
\text { lebih murah dan terjangkau } \\
\text { untuk kalangan ibu rumah } \\
\text { tangga ataupun mahasiswa. }\end{array}$ & $\begin{array}{l}\text { Harga produk national } \\
\text { brand sedikit lebih mahal } \\
\text { dibandingkan } \\
\text { private label. }\end{array}$ \\
\hline Kualitas & $\begin{array}{l}\text { Kualitas dilihat } \\
\text { kualitas produk } \\
\text { label krivate } \\
\text { bagus dengan produk } \\
\text { national brand. }\end{array}$ & $\begin{array}{l}\text { Kualitas produk national } \\
\text { brand } \\
\text { dengama bagusnya } \\
\text { label. }\end{array}$ \\
\hline Nilai Produk & $\begin{array}{l}\text { Dari } \\
\text { produk private }\end{array} \begin{array}{r}\text { untukel } \\
\text { sedikit kurang menarik } \\
\text { dibanding produk } \\
\text { brational } \\
\text { Produk private label } \\
\text { Indomaret dapat disajikan } \\
\text { sebagai alternatif produk } \\
\text { pengganti produk national } \\
\text { brand. }\end{array}$ & $\begin{array}{l}\text { Untuk kemasan produk } \\
\text { national brand lebih } \\
\text { menarik dan bagus. }\end{array}$ \\
\hline
\end{tabular}


Dari uraian dan tabel diatas, dari perhitungan Rating Scale Produk private label terletak di interval " cukup baik “ dengan nilai 900. Sedangkan dilihat dari tabel hasil wawancara bahwa harga produk private label lebih murah. Selain dari harga, kualitas produk private label yang ada di Indomaret Banjarmasin kualitasnya sama dengan produk national brand. Dalam pengemasan produk private label sedikit kurang menarik dibanding dengan produk national brand, sedangkan untuk nilai fungsi untuk produk private label dapat dijadikan pilihan alternatif untuk pengganti produknational brand.

\section{KESIMPULAN}

Berdasarkan dari hasil penelitian dan pembahasan dengan pada bab sebelumnya, maka pada bagian penutup ini peneliti dapat menarik kesimpulan sebagai berikut:

1. Penelitian ini membuktikan bahwa konsumen lebih memilih produk private label karena konsumen mempercayai bahwa harga yang relative murah dan mempunyai kualitas yang bagus.
2. Penelitian ini membuktikan bahwa persepsi konsumen mengenai produk private label terdapat empat persepsi, yaitu : persepsi nilai , persepsi harga, persepsi kemasan dan persepsi kualitas. Dari nilai fungsi produk private label Indomaret dapat disajikan sebagai alternatif pengganti produk national brand. Dilihat dari harga produk private label lebih murah dan terjangkau,. Dilihat dari kemasan untuk produk private label sedikit kurang menarik dan dilihat dari kualitas produk private label kualitasnya sama bagus dengan produk national brand.

3. Penelitian ini membuktikan bahwa persepsi konsumen mengenai produk national brand dapat dilihat dari kualitas dan kemasan. Kualitas produk national brand sama bagusnya dengan produk private label. Untuk kemasan produk national brand lebih menarik dan bagus.

4. Perbandingan persepsi konsumen mengenai produk private label dan produk national brand, dari perhitungan Rating Scale Produk 
private label terletak di interval " cukup baik “ dengan nilai 900. Sedangkan dilihat dari tabel hasil wawancara bahwa harga produk private label lebih murah. Selain dari harga, kualitas produk private label yang ada di Indomaret Banjarmasin kualitasnya sama dengan produk national brand. Dalam pengemasan produk private label sedikit kurang menarik dibanding dengan produk national brand, sedangkan untuk nilai fungsi untuk produk private label dapat dijadikan pilihan alternatif untuk pengganti produknational brand.

\section{SARAN}

1. Pihak PT Indomarco (Indomaret) cabang Banjarmasin diharapkan dapat meningkatkan kualitas dan kemasan produk private label dengan berbagai cara diantaranya, memberikan nilai manfaat apa pun terhadap pembeli dari produk private label dan mau mendengarkan apapun keluhan dari konsumen terhadap produk yang dijual.

2. Bagi Penelitian selanjutnya juga diharapkan dapat meneliti tidak hanya satu usaha retail saja sehingga hasil penelitian dapat digeneralisasikan untuk bisnis retail yang sejenis lainnya

3. Adapun saran bagi konsumen agar dapat membandingkan kualitas produk private label dengan produk sejenis, dan meningkatkan niat untuk membeli produk private label karena banyak diskon yang diberikan dalam pembelian product private label sehingga dapat menghemat pengeluaran bulanan.

\section{DAFTAR PUSTAKA}

Alma, Buchari. 2007. Manajemen Pemasaran dan Pemasaran Jasa. Bandung: Alfabeta

Aprilia Listiyani,2011. Pengaruh karakteristik Produk Terhadap Intensi Pembelian Produk Private label. Tesis

Arikunto, Suharsimi,2002. Prosedur Penelitian, Suatu Pendekatan Praktek, edisi revisi V, cetakan kedua belas, Penerbit : Rineka Cipta, Jakarta.

Durianto, Darmadi, dkk. 2004. Strategi Menaklukkan Pasar Melalui Riset Ekuitas dan Perilaku Merek, Jakarta : PT. Gramedia Pustaka Utama.

Dursun, Inci et al. 2011. Store Brand Purchase Intention: Effects of 
Risk, uality Familiarty and Store Brand Shelf Space, Journal International Strategic Management Confedence, Elseiver. Vol 24 pp 1190-1200

Fuan Li and Paul W. Miniard, 2006. On The Potential For Advertising to Facilities Trust In The Advertised Brand.

Freddy Rangkuti.2002. The Power Of Branding . Jakarta : Gramedia

Husein Umar.2002. Metode Penelitian Bisnis . Jakarta : PT Gramedia Pustaka Utama.

Indriantoro dan Supomo 2002. Metodologi Penelitian Bisnis. Yogyakarta :BPFE.

Keegan, Warren J. 2002. Global Marketing Manajement. New Jersey : Prentice Hall

Kotler, Philip. 2006. Manajemen Pemasaran Jilid I dan 2 Jakarta : Prenticehall

Kotler, Philip. 2007. Manajemen Pemasaran Jilid Edisi I2 Jilid I. Jakarta : Prenticehall

Kotler dan Amstrong 2006. Prinsip Prinsip Pemasaran.Jakarta : PT Indeks

Kotler dan Amstrong 2007. DasarDasar Pemasaran Edisi Kesembilan Jilid 7.Jakarta : PT Indeks

Ma'ruf, Hendri. 2006. Pemasaran Ritel. Jakarta : PT Gramedia Pustaka Utama.

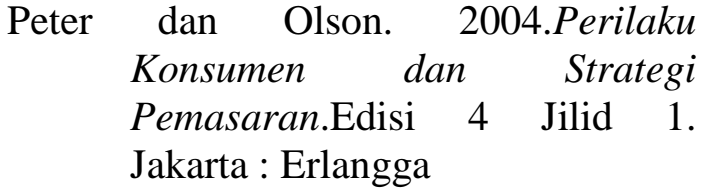

Purba, Johanes S.2012.Analisis Pengaruh Persepsi Nilai Konsumen Terhadap Minat Beli Produk Private Labels Hypermarket Carrefour Di Kota Semarang. Skripsi Program S1 Fakultas Ekonomi dan Bisnis Universitas Diponegoro. ( tidak dipublikasikan)

Purwati \& Rohmawati. (2012). Pengaruh Harga dan Kualitas Produk Terhadap Keputusan Pembelian Motor Honda Matic Beat (Studi Kasus Pada PT. Nusantara Solar Sakti). Jurnal Ekonomi Dan Informasi Akuntansi (Jenius) Vol 2 No 3.

Sekaran, U. (2006). Metode Penelitian Bisnis. Jakarta: Salemba Empat

Sopiah, \& Syihabudin. (2008). Manajemen Bisnis Ritel. Yogyakarta: CV ANDI OFFSET. Sondoh

Sugiama, A. Gima. (2008). Metode Riset Bisnis dan Manajemen. Bandung: Guardaya Intimarta

Sugiyono. (2012). Metode Penelitian Kuantitatif, Kualitatif, dan Kombinasi (Mixed Methods). Bandung: Alfabeta.

(2013). Metode Penelitian Kuantitatif Kualitatif $R \& D$. Bandung: Alfabeta -.(2014). Metode Penelitian Bisnis (Pendekatan Kuantitatif, 
Kualitatif, dan $R \& D)$. Bandung: Alfabeta. Sunyoto

Tjipyono, Fandy. 1999. Strategi Pemasaran. Yogyakarta : Andi

Utami, Christina Whidiya. 2008. Manajemen Ritel ( Strategi dan Implikasi Ritel Modern ). Jakarta : Salemba Empat

Wu, Paul C.S et al., 2011, The Effect of Store Image and Service quality on Brand Image and Purchase Intention for private label brands, Journal of Marketing Research, Vol 19 pp $30-39$.

Yoo, B., Donthu, N dan Lee, S. 2000. An Examination off Selected Marketing Mix Elements and Brand Equalty. Journal of the Academy of Marketing Science. Vol 28 No 2 pp 195 - 211

Hasil Penelusuran :

http://digilib.polban.ac.id/download.php ?id=17449

http://bba.telkomuniversity.ac.id/id/capst one-database/skripsi-mahasiswatahun-2016/ 